\title{
Old Age Health Problems among Family Members in Rural Community
}

\author{
Susheelkumar V Ronad ${ }^{1 *}$, Chetan S Patali², Shridhar H Gondbal ${ }^{3}$, Kirankumar TC ${ }^{4}$, Pankaja TC ${ }^{5}$, Rajendra \\ Badesgol ${ }^{6}$, Veeresh Nandgaon ${ }^{7}$ and Timmapur RM ${ }^{8}$ \\ ${ }^{1}$ Department of Psychiatric Nursing Dimhans Dharwad, India \\ ${ }^{2}$ Dhanush institute of Nursing Sciences Bagaklot, India
}

${ }^{3}$ Staff Nurse, Indira Gandhi Children's Hospital, India

${ }^{4}$ Department of Management Studies, Karnataka Arts College, India

${ }^{5}$ RL Law College, India

${ }^{6}$ Department of Police, India

${ }^{7}$ KLE Institute of Nursing Sciences Belgaum, India

${ }^{8}$ Psychiatric social worker, Dimhans Dharwad, India

Submission: February 08, 2018; Published: August 27, 2018

*Corresponding author: Susheelkumar V Ronad, Department of Psychiatric Nursing Dimhans Dharwad, India, Email: susheelronad@gmail.com

Keywords: Disease, Senior citizens, Ageing, Deteriorisation, Physically, Adolescence

\section{Introduction}

You must be humble enough to love, so that you will touch the hearts of others and make them think of you with love. It is better to be forgotten entirely than to be remembered without love [1]. According to the United Nations the word old age is defined an age person as one who is 60years and above. Generally, people above age of 60years are considered as senior citizens. Indian people between 60-75years are categorized as "young old" between 75-85years as "old-old" and people above the age of 85years are classified as "very old" or inferno. There is marked difference in the health needs of these age groups [15]. Ageing is a universal phenomenon old age is not in itself a disease but is a normal part of the human life span. Ageing is normal, universal, progressive, irreversible process. It is an inevitable physiological phenomenon. The human life span follows a recognized pattern birth to death. Then there is a gradual deteriorisation in physical and mental abilities. As the ageing process progress mental capabilities such as memory and physical abilities further deteriorate [6]. As the individual develops and matures socially and physically from birth through adolescence and after the age of 30years additional changes occur that reflects normal decline in all organ systems, then it is called senescence. This happens gradually throughout the body system reducing the viability of different body systems and increasing their vulnerability to disease $[7,8]$.

Recent changes in the patterns of care provision for the elderly have led to an increasing reliance on family care. For some elderly people however, the ageing process becomes a burden, they loss their independence both physically, for example through immobility and even psychologically through depression or cognitive impairment. This physical and mental decline may be compounded by poverty, rejection by friends and family [9]. The increasing proportion of elderly in the society is a worldwide phenomenon. In the 20years, between 1960 and 1980 there was a $50 \%$ increase in the number of people between 60 and 80years of age, and this trend is continuing. Most of the care of dependent older people in the community is carried out by families in the home of older person. Old age is certainly accompanied by problems for a significant number of elderly people and care of elderly people is largely concerned with assessing these problems and their compensating for them or participating in the process of helping the elderly person to overcome them and regain a degree of independence (Table 1).

The increasing population of older people has sought the attention of world community. Emphasis is given on healthy and active ageing. It implies being holistically fit, being mobile, coping well with various living activities. It is very important to take care of old people when they are not well [10-12]. Life expectancy having risen all over the world is of concern to every nation to be able to look after its elderly population and to educate them for a healthy and active ageing. As we have entered $21^{\text {st }}$ century we find that the typical age profiles of nearly all national populations has either already undergone or undergoing an enormous change. Now at least one in 15 or 16 citizens are over the age of 60 . The world health assembly 
in its resolution in 1979 called for preventive action to pay attention to the quality of life of the elderly and to find effective alternatives to the rising trend in institutional care. As now we find due to all advances in medicines and nursing care, the life span has increased. Also, the population of old people is much more than the younger people that are 9 million to 70 million in India. Almost all nations are facing the problem of caring for these people. In spite of being frail, and vulnerable, the elderly could contribute immensely to the growth of the community provided that they are properly cared for. The country has very limited number of old age home. Most of them are situated in the cities [13]. Nearly $72 \%$ of elderly live in rural and half of these are below poverty line. The remaining $28 \%$ of elderly live in urban areas. Further, about $90 \%$ of old person in India, are from unorganized sector. Around $10 \%$ of elderly belong to organized sector that have access to some distinct benefits like service pensions and health care facilities in the shape of CGHS, etc. The implication of ageing populations is earmarking lot of budget to deal with their needs and problems. It is also adding on to dependent population in India [14].

Table 1

\begin{tabular}{|c|c|c|}
\hline Sl No & Problems & Case Per 100 Problems \\
\hline 1 & Hypertension & 30 \\
\hline 2 & Arthritis & 40 \\
\hline 3 & Cataract & 20 \\
\hline 4 & Diabetes Mellitus & 10 \\
\hline
\end{tabular}

The year 1999, the last year of 20th century was dedicated by the United Nations to the older persons so as to focus attention of the people in the world on "ageing population, its issues and problems" and accordingly formulate policies and action programmes to promote health and quality of life. Healthy ageing was considered as everyone's goal and an achievement to be celebrated by society as a whole. Therefore, WHO during same year (1999) had chosen the theme for World Health Day as "Active Ageing Makes the Difference" to coincide with the international year of the older persons [15]. Ageing has become a major challenge and there is need to give more attention to care and protection for older persons. Hence, their needs for more old age homes according to the affordability of the persons concerned, which should be properly maintained, well supervised, inspected often and appraised and awarded for their maximum care give to elderly [16]. It provide effective care and protection to senior citizen against all ill treatments inflicted by their own words and also offers them a speedy in expensive legal frame work for redressed

\section{Need for the Study}

The word "aged" is relative depending upon the society. The term "Graying of Nations." "Aging of Nations" and demographic transition of "Pyramid to Pillar" are the concerns voiced all over the world. The word "geriatrics" was coined by Naseher in 1914 and, is derived from Greek word gerus \& iatrea, which means old age and treatment respectively [17]. Ageing is a universal phenomenon old age is not in itself a disease but is a normal part of the human life span. Ageing is normal universal progressive irreversible process. It is an inevitable physiological phenomenon the human life span follows a recognized pattern from birth to death there is a gradual deterioration in physical and mental capabilities, such as memory and physical abilities further deteriorate [18]. Each person experiences the ageing process differently. Some people are able to maintain lifelong health independence. While others find that they face increasingly more difficult challenges to their abilities to take care of themselves. The difficulties that ageing can bring are felt not only by elderly people but also by their children and grandchildren [19]. The dream of people all over the world to live long is now becoming a reality due to the advancement in socio-economic development and sciences, particularly medical sciences. It is estimated that there are 416 million old age people around the globe and by 2020 world's $11.9 \%$ of population will be above 60years [20].

The demographic ageing is a global phenomenon 2025 . Virtually 2(two) billion by 2050, out of these, majority the older persons will be in the developing world. United Nations Organization (UNO) estimates that presently one out of every 10 persons. The United Nation General Assembly designated as 1st October as the international day for elderly. According to WHO "Health is a state of complete physical, mental social wellbeing and not merely an absence of disease or infirmity and socially and economically productive life."

In India $7.5 \%$ of the total population is above 60years. India is still to become home to second largest member of older persons in the world. Recent statistics related to elderly people in India. (According to censes of 2001) said that as many as $75 \%$ of elderly persons were living in rural areas, about $48.2 \%$ of elderly persons were woman out of whom $55 \%$ persons were illiterate and dependent on physical labor. One thirty was reported to be living below poverty line that is $66 \%$ of older persons were vulnerable [21]. The ageing population creates a new problem that is a growing breed of care givers, who are themselves in need of care as the elder lies growing in all the degenerative changes these are hypertension, arthritis, cataract, and diabetes Mellitus.

According to WHO reports common health problems of older adults are as follows:

The study conducted on health problem among the aged persons of 60years at rural area of Calcutta. The result reveals that, main health related problems were (45.7\%) hypertension, (47.8\%) diabetes mellitus, and (54.3\%) arthritis [20]. The elders are fought with problems lone lines, lack of security, illness, and so on. But the "I am old and of one use feeling formants them most. But dear and near ones as well as the society can instill hope in them and revive them depend spirits. The increases of senior citizens around the world could soon be considered a 
problem. The fact is with number of elderly people increasing, there will be a greater need for people care them [22]. The care giver that is along with whom the elderly is staying in home is directly or indirectly responsible for the abuse of elders in their home. Population ageing creates a new problem that is a growing breed of care givers who are themselves in need of care. During community field experience the investigator visited the old age people s houses and most of their family members were unaware about the health problems and care so the investigator under took this study that is to conduct planned teaching programmed regarding care of old age health problems.

\section{References}

1. Abdellah FG (1986) Better patient care through Nursing research. Kango Tenbo 13(9): 1036-1043.

2. Alba A, Flora L, Sonia M, Pilar O, Isabel FM, et al. (2009) Hypertension in the very old; prevalence, awareness, treatment and control: a crosssectional population-based study in a Spanish municipality. BMC Geriatric 9: 16.

3. Alligood MR, Tomey A (2002) Nursing theories; Utilization and application. ( $2^{\text {nd }}$ edn). st Louis Mosby, USA.

4. Basavantappa BT (2008) A text book of "Nursing Research". (1 $1^{\text {st }}$ edn). Jayapee Brothers Medical Publishers, India.

5. Bekibele CO, Gureje 0. (2008) Impact of self reported visual impairment on quality of life in the Ibadan study of aging. $\mathrm{Br} J$ Ophthalmol 92(5): 612-615.

6. Bhatia S, Swami HM, Thakur JS, Bhatia V (2007) A study of health problems and Loneliness among the elderly in Chandigarh. Indian J Community Med 32: 255-258.

7. Carnethon MR, Yan L, Greenland P, Garside DB, Dyer AR, et al. (2008) Resting heart rate in middle age and diabetes development in older age. Diabetes Care 31(2): 335-339.

8. Carol A Miller (1999) Nursing care of older adults and practice. $\left(3^{\text {rd }}\right.$ edn). Lippincott Williams Wilkins, Phidelphia, USA. p. 724.

9. Catherine ward- Griffin (2004) Nurses as caregivers of elderly relatives: negotiating personal and professional boundaries. Can J Nurs Res 36(1): 92-114.
10. Chen YM, Chen LK, Lan JL, Chen DY (2009) Geriatric syndromes in elderly patients with rheumatoid arthritis. Rheumatology (Oxford) 48 (10):1261-1264.

11. Chou KL, Chi I (2005) Prevalence of depression among elderly Chinese with diabetes. Int J Geriatr Psychiatry 20(6): 570-575.

12. Creasia JL, Parker B (1991) Conceptual foundations of professional practice. ( $1^{\text {st }}$ edn). Mosby, USA.

13. Dane FC (1990) Research Methods. ( $1^{\text {st }}$ edn). Brooks Kale Publishing Company, California.

14. Dey AB, Soneja S, Nagarkar KM, Jhingan HP (2001) Evaluation of the health and functional status of older Indians as a prelude to the development of a health programme. Natl Med J India 14(3): 135-138.

15. Frank A Sloan, Daniel W Belsky, Idrissa A Boly (2008) Prevalence of major eye diseases among US Civil war veterans. Arch opthalmol 126 (2): 246-250.

16. Gotta M, Seymour J, Bellamy G, Clark D, Ahmedzai S (2004) Older people's views about home as a place of care at the end of life. Palliat Med 18(5): 460-467.

17. Greenberger H, Litwin H (2003) Can burdened care givers be effective facilitators of elder care- reciepient health care? J Adv Nurs 41(4): 332341.

18. Gupta HL, Yadav M, Sundarka MK, Talwar V, Saini M, et al. (2002) A study of prevalence of health problems in asymptomatic elderly individuals in Delhi. J Assoc physicians India 50: 792-795.

19. Agarwal H, Baweja S, Haldiya KR, Mathur A (2005) Prevelence of hypertension in elderly population of desert region of Rajastan. Journal of the Indian Academy of Geriatrics 1: 14-17.

20. Huang ES, Sachs GA, Chin MH (2006) Implications of new geriatric diabetes care guidelines for the assessment of quality of care in older patients. Med Care 44(4): 373-377.

21. Ioannis Anagnostopoulous, Elias zinzaras, Ioannis Alexiou, Aphrodite A Papathanasiou, Evangelos Davas, et al. (2010) The prevelance of rheumatic diseases in central Greece. BMC Musculoskelet Disord 11: 98.

22. Islam TM, Fox CS, Mann D, Muntner P (2009) Age related associations of hypertension and diabetes mellitus with chronic kidney disease. BMC Nephrol 10: 17.

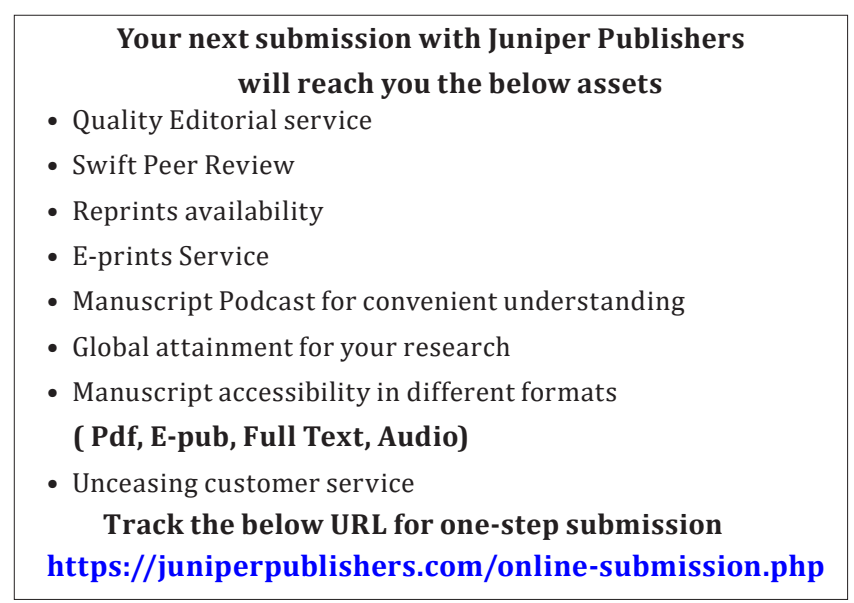

